\title{
O GOLPE DE 1964 E O REGIME DE 1968: ASPECTOS CONJUNTURAIS E VARIÁVEIS HISTÓRICAS*
}

\author{
The 1964 Military Coup and the Regime of 1968: \\ conjunctural aspects and historical variables
}

\author{
Adriano Nervo Codato**
}

[Maria Celina D'Araujo e Celso Castro] Os conspiradores discutiram algum plano de governo para fazer face aos problemas do País?

[Ernesto Geisel] "Não. O objetivo era tirar João Goulart. A idéia sobre o futuro governo era ainda muito superficial: pôr ordem no país, combater a inflação, assegurar o desenvolvimento. Eram sempre idéias muito gerais, sem coordenação. Não havia nada previsto nem quanto à ocupação dos cargos. Não tínhamos uma proposta de governo. Achávamos que esse problema iria ser resolvido depois. Em primeiro lugar, tínhamos de derrubar o Jango". Ernesto Geisel, 1997. ${ }^{1}$

\begin{abstract}
RESUMO
O trabalho trata da evolução política do Brasil num período determinado de seu desenvolvimento. Discute-se o processo de conversão do "regime autoritário" no pós-1964 em regime ditatorial-militar no pós-1968. O objetivo do artigo é examinar a causa da edição do Ato Institucional n. ${ }^{\circ} 5$, logo, da vitória da extrema-direita militar, e, portanto, do fracasso político do movimento oposicionista nessa conjuntura. A questão central que informa a análise é a seguinte: é possível encontrar uma variável explicativa na interpretação desse processo histórico que dê conta do porquê da supremacia do "grupo palaciano" (a corrente ideológica militar então mais influente), e da sua solução para a crise do regime, bem como da derrota das "oposições"?
\end{abstract}

* Versões anteriores deste trabalho foram apresentadas em duas ocasiões diferentes. O ensaio que o leitor tem em mãos retoma e amplia a conferência "Condicionantes político-militares da crise de 1968: aspectos conjunturais", apresentada no colóquio "Anos 60: releitura dos movimentos sociais", promovido pelo Programa Especial de Treinamento - Ciências Sociais (Capes/UFPR) em maio de 2003. Voltei posteriormente aos mesmos temas na palestra "Política de esquerda e luta armada no Brasil dos anos 60", proferida no evento "Representações de Gênero no Cinema", promovido pelo Grupo de Estudos e Pesquisas sobre Relações de Gênero e Tecnologia - GeTec do Cefet-PR. Nessa oportunidade, discutiu-se o filme $O$ que é isso companheiro?, de Bruno Barreto (Brasil: Columbia Tristar, 1997). Agradeço a leitura detalhada e as observações mais que pertinentes de Marcos Napolitano, do Departamento de História da Universidade Federal do Paraná.

** Universidade Federal do Paraná

1 Trecho extraído de: D’ARAÚJO, Maria Celina; CASTRO, Celso. (Orgs.). Ernesto Geisel. Rio de Janeiro: Editora Fundação Getulio Vargas, 1997. p. 162. 
O problema teórico de fundo aqui é o das determinações de um evento político, isto é, a articulação dos nexos causais que explicam determinado resultado histórico. São examinadas duas explicações correntes da literatura de Ciência Política e História Política e proposta uma terceira, que enfatiza, principalmente, variáveis de tipo ideológico.

Palavras-chave: golpe de 1964, crise de 1968, Ato Institucional n. 5, explicação histórica.

\begin{abstract}
This paper analyses Brazil's political evolution during a specific moment. It discusses the processes of conversion of the post-1964 "authoritarian regime" to the post-1968 regime of military dictatorship. The article's principal aim is to examine the reasons for the issuing of Institutional Act 5, which meant the victory of the military's extreme right-wing and therefore the political defeat of opposition forces. The central issue informing the analysis is the question of whether it is possible to find an explanatory variable for the interpretation of this historical process that could account for the supremacy of the "grupo palaciano" (the most influential ideological current within the military corporation at that time) and their particular solution for the military crisis, as well as for the defeat of "opposition" forces. The underlying political problem here regards the factors that determine political events, that is, the articulation of causal links that can explain a particular historical result. Two common explanations in Political Science's and Political History's literature are explored and a third explanation is proposed, one that places particular emphasis on ideological variables.
\end{abstract}

Key-words: The 1964 Coup, the 1968 political crisis, Institutional Act 5, historical explanation.

O ano de 1964 só se consuma politicamente em 1968. Isto é: o golpe político-militar de 31 de março/1 de abril de 1964 somente se concretiza como regime ditatorial-militar em 13 de dezembro de 1968, após a edição do Ato Institucional n. 5.

Essa constatação banal, do ponto de vista histórico (e historiográfico), adquire algum interesse se puder ser explicada, pela Sociologia Política, em função de duas dimensões complementares: a político-social e a político-militar. A primeira diz respeito, em termos genéricos e imprecisos, à "sociedade"; a segunda, ao "Estado". Isso significa que o entendimento da evolução de um regime político de exceção - esse é o problema "empírico" tratado aqui requer uma atenção específica à cena política e à dinâmica interna do aparelho do Estado (além, evidentemente, da relação entre essas duas "esferas"). A 
análise dos conflitos entre classes, partidos, dissidências, organizações, frentes políticas, "movimentos" etc. (na linguagem usual: a "competição política") tem de ser complementada, necessariamente, pela compreensão das relações de força e influência entre grupos, cliques, facções no interior do Estado.

Tendo presente esses parâmetros de análise, não se poderia, portanto, sustentar simplesmente que "os momentos de intensificação do autoritarismo (...) decorrem em linha direta do golpe de 64". Daí que "o movimento de março não possa ser erigido em principal fator explicativo de eclosões autoritárias posteriores". Portanto, qualquer análise mais complexa da história política do regime político deve levar em conta necessariamente o comportamento da "sociedade" ou, no caso que aqui nos interessa, das "oposições".

O estudo de Maria Helena Moreira Alves comprovou que formas específicas de controle tiveram de ser criadas em resposta a desafios apresentados pela sociedade civil (...) Estes períodos (de intensificação do movimento oposicionista) determinaram a reorganização das estruturas de Estado, de modo a desenvolver novos mecanismos de controle e impor novamente a conformidade. ${ }^{3}$

Igualmente, é preciso enxergar de perto o que se passa no "Estado". É desnecessário lembrar que, nos regimes ditatorial-militares, as Forças Armadas assumem o papel dominante porque controlam os "postos de comando essenciais" e os "centros de poder real" do sistema institucional dos aparelhos do Estado". Isso implica em investigar as lutas internas em torno de projetos políticos específicos que se desenvolvem no próprio seio do aparelho militar.

Alfred Stepan foi o primeiro autor a chamar a atenção para a diferenciação de grupos no interior das Forças Armadas no Brasil. Ele insistiu particularmente na existência de uma corrente "profissional", vinculada à Escola Superior de Guerra, e reunida em torno do marechal Castello Branco. O corolário

2 CRUZ, Sebastião Velasco; MARTINS, Carlos Estevam. De Castello a Figueiredo: uma incursão na pré-história da “abertura”. In: SORJ, Bernardo; ALMEIDA, Maria Hermínia Tavares de. (Orgs.). Sociedade e política no Brasil pós-64. 2. ${ }^{a}$ ed. São Paulo: Brasiliense, 1984. p. 15. Complementando a idéia: “...a oposição é parte integrante do sistema político, não podendo a história deste ser indiferente às concepções e aos comportamentos daquela". Id.

3 ALVES, Maria Helena Moreira. Estado e oposição no Brasil (1964-1984). Petrópolis: Vozes, 1984. p. 315.

4 POUlantZAS, Nicos. La crise des dictatures. Portugal, Grèce, Espagne. Paris: Seuil, s.d. p. $122-123$ 
dessa idéia pode ser encontrado na representação "dualista" da dinâmica política do aparelho militar no pós-64. Ela viu o panorama militar como dividido entre duas forças fundamentais: castellista ou esguiana e a "linha dura" ou "radical". João Roberto Martins Filho apresentou uma interpretação mais sofisticada da fragmentação do aparelho militar no Brasil no período que vai da posse de Costa e Silva, em março de 1967, até a eclosão da crise política em abril de 1968, como estando dividido em quatro correntes políticas: castellistas; albuquerquistas; linha dura; e palacianos. ${ }^{5}$ Essa nos parece a visão mais adequada para compreender a luta política interna do Estado.

Retomando o fio da argumentação. A evolução do regime ditatorialmilitar no Brasil esteve marcada, como se sabe, por ciclos de "repressão" intensificação do autoritarismo - e ciclos de "liberalização" - atenuação das restrições sobre a atividade política. Essa história, representada esquematicamente pelo quadro 1, torna evidente o caráter não-linear da política nacional entre 1964 e 1985.

A enumeração sumária de acontecimentos acima é, contudo, muito mais ilustrativa que explicativa. Ela informa bem o que aconteceu durante o "regime autoritário", mas deixa em aberto duas questões essenciais: "como isso aconteceu?" e "por que isso aconteceu assim (e não de outra forma)?". Se não se quiser oferecer uma resposta genérica a essas perguntas, é preciso

\section{QUADRO 1 - CICLOS POLÍTICOS DO REGIME DITATORIAL-MILITAR}

\begin{tabular}{|l|l|}
\hline \multicolumn{1}{|c|}{ ciclos de "repressão" } & \multicolumn{1}{|c|}{ ciclos de "liberalização" } \\
\hline $\begin{array}{l}\text { 1) 1964-1965: eliminação dos atores políticos ligados ao populismo } \\
\text { (lideres partidários, sindicais) e a posições de "esquerda" em geral (AI-2); }\end{array}$ & $\begin{array}{l}\text { 1)1965: adoção de uma "política de retorno à normalidade" pelo governo } \\
\text { Castello Branco, a fim de "constitucionalizar" o regime (AI-4); }\end{array}$ \\
\hline $\begin{array}{l}\text { 2) 1966-1967: consumação dos expurgos políticos após a edição do Ato } \\
\text { Institucional n. 2 em outubro de 1965; }\end{array}$ & $\begin{array}{l}\text { 2) 1967-1968: adoção da "politica de alivio" pelo governo de Costa e } \\
\text { Silva, que envolvia tentativas de negociação com a oposição; }\end{array}$ \\
\hline $\begin{array}{l}\text { 3) 1969-1973: enfrentamentos com a luta armada e constituição de um } \\
\text { aparelho repressivo-militar; }\end{array}$ & 3) 1974-1976: "política de distensão", adotada no início do governo Geisel; \\
\hline $\begin{array}{l}\text { 4) 1975-1976: concentração da repressão em São Paulo a fim de enfrentar } \\
\text { a emergência de uma grande frente de oposição; }\end{array}$ & $\begin{array}{l}\text { 4) 1977-1979: retomada da "distensão" pelo governo Geisel após o "pacote } \\
\text { de abril" de 1977, tendo como objetivo final a revogação do Ato } \\
\text { Institucional n. 5; }\end{array}$ \\
\hline $\begin{array}{l}\text { 5) 1979-1984: repressão aos movimentos sociais de trabalhadores rurais e } \\
\text { urbanos, principalmente o novo movimento sindical. }\end{array}$ & $\begin{array}{l}\text { 5) 1979-1984: continuidade da "política de distensão" na "politica de } \\
\text { Abertura" do governo Figueiredo. }\end{array}$ \\
\hline
\end{tabular}

5 Cf. respectivamente: STEPAN, Alfred. The Military in Politics. Changing Patterns in Brazil. Princeton: Princeton University Press, 1971; OLIVEIRA, Eliézer Rizzo. Conflits militaires et décisions sous la présidence du Général Geisel. In: ROUQUIÉ, Alain. (Dir.). Les partis militaires au Brésil. Paris: Presses de la FNSP, 1980; e MARTINS FILHO, João Roberto. O palácio e a caserna: a dinâmica militar das crises políticas na ditadura (1964-1969). São Carlos: Editora da UFSCar, 1995, especialmente o cap. IV. 
recortar, nessa longa seqüência factual, um subperíodo determinado a fim de comentá-lo em profundidade. Esse recurso metodológico simples exige do analista uma visão muito mais detalhada dos processos políticos concretos e sugere que se dê mais atenção a determinações de tipo conjuntural que estrutural.

O objetivo geral deste ensaio é refletir sobre o processo de conversão do "regime autoritário" brasileiro no pós-64 (na verdade, um sistema político que se definia, inicialmente, muito mais por suas características negativas do que por suas instituições específicas: anticomunista, antipopulista, e adepto de um moralismo reformador bastante vago: "contra a corrupção") em regime ditatorial-militar no pós-68.

É preciso, assim, fixar desde logo quatro pressupostos que informam nossa análise: a) a configuração política que decorre imediatamente do golpe de 1964 é resultado de um "autoritarismo de crise" e não de um projeto das Forças Armadas para se constituir como grupo politicamente dirigente; b) a militarização do sistema político e o controle estrito da cena política pelas Forças Armadas foram antes um processo que um evento (ou um "fato"); c) esse processo de militarização do sistema estatal é simultâneo ao processo de centralização do poder decisório na cúpula do executivo federal e a sua causa mediata; e, por fim, d) o ponto culminante desses dois processos é o período 19691979 e esse encontro não é explicável sem referência aos conflitos políticos e sociais de 1968; principalmente à sua forma de solução.

O ano de 1968 é, assim, uma data fundamental na evolução política do regime ditatorial-militar brasileiro. Dois eventos - opostos entre si - são representativos dessa dinâmica processual e contraditória: a "Passeata dos Cem Mil" e o "Ato Institucional n. 5". A Passeata, em 26 de junho, no Rio de Janeiro, resume a disposição de vários setores sociais para confrontar o processo de militarização do Estado, a política econômica "recessiva" e a restrição das "liberdades". A oposição política, até então difusa e desarticulada, incapaz de ser representada pela Frente Ampla, assume aí uma característica de "massa". O AI - 5, em 13 de dezembro, simboliza o ponto decisivo de inflexão do regime e o momento paradigmático do processo de reforço da centralização militar do poder de Estado. Os limites severos fixados à atividade política e aos direitos civis revelam a disposição em continuar, agora em estágio superior, o

6 SAES, Décio. Classe média e sistema político no Brasil. São Paulo: T. A. Queiroz, 1984. p. 153.

7 MORAES, João Quartim de. Les militaires et les régimes politiques au Brésil de Deodoro à Figueiredo (1889-1979). Thèse, Paris, 1982. (Doctorat d'Etat). - Institut d'Etudes Politiques de Paris, p. 665 . 
"movimento de 31 de março de 1964" e restringem bruscamente a possibilidade da retomada do controle civil sobre a "Revolução". ${ }^{8}$

O objetivo específico deste artigo é examinar a causa, ou as causas principais, da edição do AI-5, logo, da vitória da extrema-direita militar, e, portanto, do fracasso político do movimento oposicionista na conjuntura de 1968. É possível encontrar uma variável explicativa na interpretação desse processo histórico 9 que dê conta do porquê da supremacia do "grupo palaciano" (a corrente ideológica militar mais influente nessa conjuntura) e da derrota das "oposições" (aí incluídas a estudantil, a política, a parlamentar, a operária e as organizações clandestinas de luta armada)? O problema teórico de fundo aqui é, portanto, o das determinações de um evento político. Isto é: a articulação dos nexos causais que explicam determinado resultado histórico - o fechamento da cena política e a transformação interna do regime; numa palavra, o aprofundamento da ditadura.

$\mathrm{O}$ texto que segue está dividido em três partes. Na primeira procuro evidenciar os traços principais do regime brasileiro no imediato pós-64 e menciono brevemente os eventos decisivos da conjuntura 1967-1968. A segunda parte é, na verdade, uma revisão da literatura a respeito das explicações sobre os fatores determinantes da solução autoritária para a crise de 1968. Na última parte tento formular uma hipótese alternativa às existentes para pensar o 13 de dezembro. A comprovação dessa hipótese dependerá, contudo, de pesquisas posteriores.

8 Fernando Henrique Cardoso sublinha que "a aceitação pela burguesia, no primeiro momento [i.e., em 1964] do aumento de interferência militar para" desarticular os "instrumentos de pressão e defesa das classes populares" custará, "nos momentos seguintes, a impossibilidade de retomada do controle civil do processo político. Para conter a 'pressão de baixo' foram tomadas medidas que implicaram não apenas na liquidação do regime populista, mas da própria expressão política direta da burguesia: o sistema de partidos ficou à margem do sistema de decisões", por exemplo. CARDOSO, Fernando Henrique. O modelo político brasileiro e outros ensaios. 4. ed. São Paulo; Rio de Janeiro: Difel, 1979. p. 55. O ato 5, em fins de 1968, radicalizou essa impossibilidade.

9 Se é desejável é outro problema. A anedota contada (e vivida) por John Gaddis separa bem os estilos intelectuais, e principalmente os procedimentos metodológicos, entre historiadores e cientistas políticos. Enquanto os primeiros crêem na interdependência das variáveis, os últimos (ao menos os da corrente dominante) preocupam-se, na análise de um "caso", em isolar a variável independente (a causa). Daí a pergunta desconcertante feita por Gaddis num colóquio de cientistas políticos: "Como, à parte Deus, se ele ou ela existe, pode haver uma variável independente? Todas as variáveis não dependem umas das outras?”. GADDIS, John Lewis. Paisagens da História: como os historiadores mapeiam o passado. Rio de Janeiro: Campus, 2003, p. 70-71. Uma discussão sobre "como se escreve a história" nos levaria longe demais. Penso que é suficiente enfatizar aqui um princípio adequado quando se trata da causalidade histórica. "Um fenômeno histórico (seja ele um evento ou um processo) não se explica, em geral, apenas por uma série de antecedentes, mas constitui o efeito combinado do entrecruzamento, num determinado "ponto", de múltiplos fatores causais, vale dizer, de múltiplas séries de antecedentes". MORAES, João Quartim de. A mobilização democrática e o desencadeamento da luta armada no Brasil em 1968: notas historiográficas e observações críticas. Tempo Social, São Paulo, v. 1, n. 2, jan./jun. 1989. p. 141. 


\section{O regime político pós-64}

A dinâmica (processual) e sua natureza (contínua) da "Revolução de 1964" já estão anunciadas na declaração do presidente Castello Branco em 27 de outubro de 1965 “à Nação": "No preâmbulo do Ato [1] que iniciou a institucionalização do movimento de 31 de março (...) não se disse que a Revolução foi, mas que é e continuará". ${ }^{10}$

Ainda que as Forças Armadas não possuíssem de antemão um "projeto" (de governo, para o país etc.), a dinâmica do processo político entre abril de 1964 e outubro de 1965 indicava que a derrota definitiva do "populismo" - de sua agenda reformista, de suas lideranças "carismáticas" e de seus mecanismos de controle político e participação das massas - exigiria mais que um governo de emergência e uma intervenção moderadora. O período que vai de março de 1967 a outubro de 1968 tornou evidente a baixa institucionalização das medidas autoritárias (apesar da intensidade da "repressão" inicial), a legitimidade cada vez mais restrita do pronunciamento militar e a rearticulação das forças político-sociais do pré-64, agora sob liderança do movimento estudantil, e não mais dos políticos "populistas". Assim, a "Revolução", de fato, continuou. Seu maior impulso foi, como se verá, o Ato Institucional n. 5. Por meio dele, o presidente da República poderia (como de fato o fez) decretar o recesso do Congresso Nacional, das Assembléias Legislativas e das Câmaras de Vereadores (Art. 2. ${ }^{\circ}$ ); suspender os direitos políticos de quaisquer cidadãos pelo prazo de dez anos e cassar mandatos eletivos federais, estaduais e municipais (Art. $4 .^{\circ}$ ); suspender as garantias constitucionais ou legais de: vitaliciedade, inamovibilidade e estabilidade (Art. $6 .^{\circ}$ ); suspender a garantia de habeas corpus, nos casos de crimes políticos contra a segurança nacional, a ordem econômica e social e a economia popular (Art. 10). ${ }^{11}$

Uma análise, mesmo sumária, do significado do AI-5 para a evolução do regime político não pode, contudo, ficar nas declarações corretas, mas gerais, do tipo: "as Forças Armadas se tornaram o Poder Dirigente sobre a Nação", abandonando a função política moderadora ("bonapartista"), típica do pré-64. ${ }^{12}$ É certo que os golpes de março de 1964 no Brasil e de junho de 1966 na Argentina (e,

10 Ato Institucional n. 2, Preâmbulo. Todas as referências aos Atos Institucionais serão feitas a partir de: BONAVIDES, Paulo. História constitucional do Brasil. 3. ed. Rio de Janeiro: Paz e Terra, 1991. Anexo "Documentos da Carta de 1967 e do período de exceção", p. 769-794.

11 Ato Institucional n. 5. In: BONAVIDES, op. cit., p. 788 et seq.

12 DREIFUSS, René A.; DULCI, Otávio S. As forças armadas e a política. In: SORJ; ALMEIDA, op. cit., p. 94. 
posteriormente, o de 1976) - e também os golpes militares de 1973 no Chile e no Uruguai - inauguraram um período de dominação dos militares enquanto instituição. Nada mais distante, portanto, das formas de autoritarismo tradicionais (baseadas ou no "carisma" do líder político ou no despotismo pessoal), do fascismo, do bonapartismo etc. ${ }^{13}$ Mas os traços característicos desse "novo autoritarismo" não foram produzidos num golpe. Por isso, para evitar anacronismos, é necessário recuperar a dinâmica histórica e atentar para a periodização especificamente política (referida acima) a fim de compreender o processo de transformação interna do regime.

A história que está na base de uma série de "acontecimentos" - a rearticulação política do populismo (1965-1966), o crescimento da oposição ao segundo governo militar (1967-1968) e a edição de medidas ultra-repressivas (1968) - pode ser recontada brevemente a partir dos preâmbulos dos Atos Institucionais e das providências práticas que eles estipularam. ${ }^{14}$

É preciso notar, antes de tudo, que a ação militar em 1964 foi reativa. Na visão das próprias Forças Armadas, tratou-se de deter "o caos, a desordem e a instabilidade política" ${ }^{15}$ A tradução dessa ambição salvacionista - simplesmente a "reconstrução econômica, financeira, política e moral do Brasil" (Ato 1, Preâmbulo) - está basicamente atada ao propósito de destruir o populismo (representado pelo governo Goulart) e suas consequiências políticas nefastas: a "corrupção" e a "subversão" (Ato 2, Preâmbulo). Sob esses lemas genéricos estão abrigados os móveis reais que empurram mais uma vez as cúpulas das Forças Armadas a intervir na política civil: a radicalização do movimento nacional-popular a partir de fins de 1963 (cujo ponto máximo foi o Comício das Reformas em meados de março de 1964) e a subversão da hierarquia militar, avalizada pelo próprio Presidente (cujo ponto culminante foi o discurso no Automóvel Clube em fins de março de 1964). Assim, aparentemente, a única tarefa dos militares deveria limitar-se a promover a exclusão política das classes populares, desarticulando, pela repressão, suas instituições de organização sindical (o CGT, principalmente) e participação autônoma (como foi

13 O’Donnell sugeriu o termo "Estados burocrático-autoritários" para designar esse tipo de regime político. Ver: O'DONNELL, Guillermo. Reflexiones sobre las tendencias de cambio del Estado burocrático-autoritario. Revista Mexicana de Sociología, México, v. 39, n. 1, ene./mar. 1977. Para uma crítica a essa e outras classificações da forma de dominação política na América Latina nos anos setenta, ver: FERNANDES, Florestan. Apontamentos sobre a "Teoria do Autoritarismo". São Paulo: Hucitec, 1979.

14 A sugestão de tomar os Atos Institucionais como fonte para descrever/explicar a conjuntura 19641968 veio de SAES, op cit., p. 167-169 e de OLIVEIRA, Eliézer Rizzo. As forças armadas: política e ideologia no Brasil (1964-1969). Petrópolis: Vozes, 1976.

15 Gláucio Ary Dillon Soares analisa as explicações acadêmicas para o golpe militar de 1964 e as confronta com a visão que os próprios militares ofereceram da conspiração, do golpe e do regime ditatorial. O "caos" é, para esses últimos, a justificativa mais freqüente alegada para a intervenção. Cf. O golpe de 64. In: SOARES, Gláucio Ary Dillon; D’ARAÚJO. Maria Celina (Orgs.). 21 anos de regime militar: balanços e perspectivas. Rio de Janeiro: Ed. da FGV, 1994. p. 36-37/(especialmente). 
o caso das "Ligas Camponesas"), além do seu canal parlamentar privilegiado (o PTB). As cassações de parlamentares ligados ao janguismo, as aposentadorias compulsórias e as depurações nas Forças Armadas e no Judiciário complementariam esses objetivos limitados, resumidos numa única oração: "drenar o bolsão comunista cuja purulência já se havia infiltrado não só na cúpula do governo como nas suas dependências administrativas" (Ato 1, Preâmbulo). O autoritarismo dessa primeira etapa, que vai grosso modo de abril de 1964 a outubro de 1965, decorria, portanto, mais da conjuntura "excepcional" na qual ele era exercido do que de uma ideologia sistematicamente elaborada; tratava-se de uma ditadura provisória ou de um "autoritarismo de crise". ${ }^{16}$

Daí decorre o seguinte: a militarização do sistema político é progressiva e só começa a ser de fato reconhecida quando são impostas restrições específicas sobre a atuação e a organização da "classe política". Ela é paralela, mas não se confunde, com a militarização do sistema estatal, que vai do topo do aparelho do Estado (a sua face mais visível: a Presidência da República) para a base (os escalões médios da burocracia) seguindo um ritmo mais lento, porém igualmente contínuo. O Ato Institucional n. 2 (de outubro de 1965) marca uma inflexão: suprime os partidos populistas (Art. 18) ${ }^{17}$ e determina que todas as eleições presidenciais serão, a partir de então, indiretas (Art. 9. ${ }^{\circ}$ ). O Ato 3 (Art. 1. ${ }^{\circ}$ ) estipula, em fevereiro de 1966, em nome dos "superiores objetivos da Revolução", o mesmo regime eleitoral para os governadores e a nomeação dos prefeitos das capitais pelos últimos (Art. $4 .^{\circ}$ ) As duas decisões consideravam a "necessidade de preservar a tranqüilidade e a harmonia política e social do país" (Ato 3, Preâmbulo) e estavam motivadas muito mais pela visão propriamente

16 Para a expressão, ver: SAES, op. cit. Cap. 3. É nesse sentido preciso que não se pode falar em um "projeto" consciente e articulado das Forças Armadas que guiará a intervenção política, a constituição dos governos militares e a adoção de um "modelo político" e, principalmente, de um "modelo econômico" no pós-1964. Ainda que houvesse grupos que desde o fim dos anos cinqüenta apresentassem suas próprias soluções para o problema do "atraso brasileiro" - como foi o caso, da esquerda para a direita, do PCB, do ISEB e da ESG/IPES , a dinâmica política (no plano "tático") ultrapassou a dinâmica propriamente ideológica (no plano "estratégico"). Conclusão: os vários eixos da conspiração contra o regime da Constituição de 1946, simbolizados pelas ações, na cena política, de certas lideranças (Prestes, Brizola, Lacerda, Castello Branco, Jango etc.), disputavam entre si a primazia para impor os seus projetos respectivos para o "desenvolvimento nacional" ainda que não tivessem muita clareza nem a respeito do seu conteúdo, nem dos meios políticos para concretizá-lo. Esses ideários vagos de cada corrente política (uns mais, outros menos) servirão, contudo, de referência básica à medida que o processo político vá definindo não só quem fará parte da nova estrutura de poder, mas principalmente da hierarquia específica das facções civis e militares em seu interior. A história aqui contada é assim a história de três derrotas: 1964 - derrota das "esquerdas"; 1965 - derrota da corrente civil liberal; 1968 - derrota das oposições "democráticas" e da facção militar que previra uma intervenção política mais temporária que permanente.

17 A causa direta para a edição do Ato 2 foi a vitória de políticos tradicionais do PSD nas eleições para os governos da Guanabara e de Minas Gerais e representou, para os "revolucionários" mais radicais, a rearticulação das forças políticas populistas recém-derrotadas em abril de 1964. 
militar do processo político do que pelos princípios liberal-democráticos dos setores civis da coalizão golpista.

O processo de militarização implicou também uma severa readequação da estrutura burocrática do Estado. À medida que os dois movimentos descritos acima seguiram, seguiu também a adoção de uma série de medidas que alteraram a correlação de forças entre os ramos do aparelho do Estado: assiste-se, então, à ascendência do Executivo sobre o Legislativo/Judiciário e, simultaneamente, a centralização do processo decisório em nível federal. Essa nova relação de forças foi institucionalizada por uma profunda modificação dos próprios "ramos" do aparelho do Estado. A reforma administrativa (decreto-lei n. 200, de 1967) incumbiu-se da tarefa de modernizar essa estrutura.

A resposta da "sociedade civil" ao aumento progressivo e aparentemente irresistível do poder das cúpulas militares sobre os recursos políticos irá configurar a mais importante crise do regime - em 1968.

Os acontecimentos políticos da conjuntura 1967-1968 permitem observar o primeiro enfrentamento importante entre as forças no poder desde abril de 1964 (os "militares") e os setores politicamente excluídos (as "oposições"). O seu resultado determinará a forma do regime. Assim, não seria exatamente correto afirmar, a menos que se conte a história do fim para o começo, que "a militarização do aparelho do Estado brasileiro definiu-se progressivamente, desde 1964, como uma tendência permanente e irreversível". ${ }^{18}$ Recordemos rapidamente os eventos decisivos desse curto período. ${ }^{19}$

Costa e Silva assumiu o governo (em março de 1967) prometendo restabelecer os processos político-representativos normais. O Marechal comprometia-se com uma política de liberação controlada (a "política de alívio"), fazendo um apelo à "união nacional". Podia-se fazer concessões limitadas à "classe política" desde que se conseguisse apoio para "reconstitucionalizar" o regime e ampliar sua legitimidade. O sub-período que então se abriu - março de 1967 a março de 1968 - correspondeu simultaneamente a uma transformação interna do regime de exceção (sua "liberalização") e uma significativa reestruturação do grupo dirigente graças à substituição do "partido" no poder. Os castellistas, dominantes na primeira fase (abril de 1964/fevereiro de 1967)

18 SAES, op. cit., p. 154 , grifos meus.

19 Uma competente descrição dessa conjuntura pode ser lida em GOMES, Lúcia M. Gaspar. Cronologia do primeiro ano do governo Costa e Silva. Dados, n. 4, p. 199-220, 1968; e MAGALHÃES, Irene Maria et al. Segundo e terceiro ano de governo Costa e Silva. Dados, n. 8, p. 152-233, 1971. A parte que segue é uma condensação do trabalho não publicado de CODATO, Adriano Nervo. Determinantes da crise política de 1968: conflitos militares e lutas sociais. Departamento de Ciências Sociais/Universidade Federal do Paraná, 1997, digit. 
cederam espaço a outras correntes (os "duros", os nacionalistas de direita e os "palacianos"), o que aprofundou a crise ideológica latente no interior da coalizão politicamente dominante. A contradição entre a antiga ideologia liberaldemocrática de matriz udenista e as práticas repressivas exigidas pela política autoritária de desenvolvimento evidenciou a divisão das Forças Armadas, favorecendo a irrupção da crise no nível da sociedade..$^{20}$ É nessa conjuntura que ganha força uma "Frente Ampla" de oposição ao governo que reúne antigos setores da "classe política" (Lacerda, Juscelino, Jânio). O movimento estudantil, por sua vez, mobiliza-se basicamente em torno da discussão sobre a política educacional do Estado ditatorial (a condenação do acordo MEC-Usaid, a questão dos "excedentes" etc.). Somente entre março e maio de 1967, há quarenta e três manifestações de protesto. ${ }^{21}$ Incidentalmente acentua-se a tendência ao afastamento progressivo de setores importantes da Igreja em relação ao "regime militar" à medida que a luta oposicionista passa a encontrar respaldo na cúpula católica, especialmente na Confederação Nacional dos Bispos do Brasil. As relações entre o Executivo e o Legislativo são também bastante precárias, visto que o primeiro não consegue estabelecer um controle sequer sobre os setores arenistas. A oposição parlamentar utiliza freqüentemente o recurso das comissões parlamentares de inquérito como instrumento de controle das atividades do governo. Ao mesmo tempo, representantes políticos da oposição compõem uma frente com a finalidade de impedir a aprovação de certos projetos do Executivo de natureza econômica, bem como pleiteiam que o presidente abandone a legislação por decreto em matérias dessa natureza. O MDB se baterá, durante todo o período, pela revogação da legislação de Segurança Nacional, pelo restabelecimento das eleições diretas, abolidas um ano antes, e pela concessão da anistia aos presos políticos e aos políticos cassados. ${ }^{22}$

Em 1968, mais precisamente de março a outubro, há uma redefinição importante dos objetivos e dos métodos da luta política do movimento estudantil. Apenas no primeiro semestre, são registradas cinqüenta e seis manifestações antiditatoriais estudantis, mobilizando mais de trezentas mil pessoas. Isso corresponde a uma maior politização do movimento estudantil. Um dos acontecimentos que inicia a crise desse subperíodo é a morte do estudante Edson Luis de Lima Souto, em 28 de abril num choque com a Polícia Militar durante uma manifestação estudantil no Rio de Janeiro. Esse episódio polariza

20 Cf. SAES, op. cit., p. 195-196.

21 Cf. MARTINS FILHO, João Roberto. Movimento estudantil e ditadura militar: 1964-1968. Campinas: Papirus, 1987. "Quadros", p. 151-153.

22 Cf. OLIVEIRA, op. cit., p. 89. 
uma onda de protestos que termina na Passeata dos Cem Mil dois meses depois. $\mathrm{O}$ assassinato, assegura Elio Gaspari, "haveria de se tornar a encruzilhada de todas as raivas" contra os militares. ${ }^{23}$

De um ponto de vista mais geral, "a intensificação do protesto estudantil, favorecida pela liberalização [de 1967-1968] constituirá o fator imediato da eclosão das manifestações antiditatoriais das camadas médias tradicionais": os profissionais liberais (liderados pela OAB) e o "movimento feminino", que ressurge então depois das "Marchas da Família" de março de 1964 com uma prédica oposta. A onda de protestos conduzida pelas vanguardas estudantis encontrará, assim, "sua 'massa' não apenas nas bases estudantis, mas também em outros setores sociais como as camadas médias tradicionais". Embora essa aliança nunca tenha sido integral, dois elementos permitiram tal encontro político: a) o caráter antiditatorial e anti-repressivo de suas manifestações e b) o efeito social provocado pela política econômica excludente. Nesse sentido, são paradigmáticos dessa "aliança" o "Dia do Luto" no Rio de Janeiro, onde cerca de 50 mil pessoas acompanharam o enterro de Edson Luís em 30 de março, além da própria manifestação dos Cem Mil. ${ }^{24}$

Do lado da oposição operária, nessa conjuntura de 1968 se esboçam dois movimentos divergentes da orientação populista tanto no plano da orientação, quanto no plano da organização. Tal atitude se exprimirá através das experiências grevistas de Contagem (abril) e Osasco (julho), onde menos a espontaneidade "autonomista" e mais a organização e orientação de agrupamentos de esquerda deslocam para as comissões de fábrica o eixo da ação operária anti-governamental. ${ }^{25}$

Nesse contexto, cresce a tendência, no seio do governo, a resolver a crise política através do encurtamento de todo espaço para a agitação popular. O foco é principalmente o movimento estudantil. Depois da ocupação da UnB, em fins de agosto, ocorrem três importantes episódios em outubro: a invasão da Faculdade de Filosofia de São Paulo pelo grupo proto-fascista Comando de Caça aos Comunistas (CCC), auxiliado pela força pública e pela Frente Anticomunista (FAC), a ação militar na USP e a prisão de 739 estudantes que participavam do $30{ }^{\circ}$ Congresso da UNE em Ibiúna. Destituído de sua vanguarda, o movimento de massas entrará em refluxo. O caso do deputado Moreira Alves fornece apenas o pretexto útil para a decretação do Ato 5 em 13 de dezembro.

23 GASPARI, Elio. A ditadura envergonhada. São Paulo: Cia. das Letras, 2002. p. 278.

24 Cf. SAES, op. cit., p. 205-206.

25 Cf. GORENDER, Jacob. Combate nas trevas. A esquerda brasileira: das ilusões perdidas à luta armada. São Paulo: Ática. 1987. p. 145. 


\section{$O$ "fechamento ditatorial": interpretações concorrentes}

Há, na literatura, duas teses disponíveis e que sustentam explicações opostas sobre a causa da edição AI-5, evento que encerra esse primeiro grande ciclo político do regime. A primeira explicação (que na verdade pode ser desdobrada em duas variantes) enfatiza a ação de certos fatores internos ao aparelho do Estado. A segunda explicação (que também pode ser desdobrada em duas variantes) enfatiza certos fatores externos ao aparelho do Estado, fatores que atuaram no nível da cena política. Vejamos muito brevemente essas explicações. A fim de resumi-las e marcar suas diferenças e ênfases vou apresentá-las sob a forma de quatro hipóteses.

Hipótese 1: o AI-5 foi, na verdade, o resultado dos embates políticos e ideológicos travados pelos diferentes grupos militares (mais moderados, mais radicais) a propósito da natureza do regime político no pós-1964. Ele representou, enfim, a vitória da "linha dura", a facção mais repressiva, sobre os "castellistas", a facção mais legalista.

Essa interpretação, que privilegia as disputas internas às Forças Armadas, toma como óbvio que

como o poder está com os militares e (por isso) como serão eles que irão definir os seus termos atuais e futuros, é claro que a disputa política se deslocou para seu âmbito, onde se formam grupos, facções e setores, os quais, unidos pela concepção comum do sistema e aliados na observação de certos postulados, tendem a se dividir em partidos internos que lutam pela conquista do poder. ${ }^{26}$

O vencedor imprimirá, portanto, ao regime resultante os seus desígnios. A "linha dura", que pretendia uma intervenção militar mais duradoura e uma repressão mais saneadora (do comunismo e da corrupção), bateu-se pela ditadura aberta. Daí a exigência de um instrumento legal para concretizar esses objetivos.

Hipótese 2: uma outra vertente dessa explicação "internalista" sustenta que o Ato 5 foi, na verdade, o produto político de uma manobra muito bem articulada pelos setores mais radicais das Forças Armadas (setores esses dominantes na coalizão militar que sustentava o governo Costa e Silva), e que

26 CASTELlO BRANCO, Carlos. Os militares no poder. Rio de Janeiro: Nova Fronteira, 1978. p. 60. v. 2: O Ato 5 . 
utilizaram as manifestações de oposição à ditadura como um pretexto para impor uma solução de força para a crise política e ampliar a militarização do regime - seu propósito desde sempre. Na versão curta do ex-Ministro da Fazenda Delfim Netto, "havia muita tensão, mas no fundo era tudo teatro. Havia passeatas, havia descontentamento militar, mas havia sobretudo teatro. Era um teatro para levar ao Ato. (...) O que se preparava era uma ditadura mesmo". ${ }^{27}$

João Roberto Martins Filho propõe a mesma razão:

ao mesmo tempo em que surgiam os primeiros sinais de radicalização da luta popular e das práticas da esquerda, em 1968, setores significativos das Forças Armadas, designados em geral como a "linha dura" e que ocupavam postos-chave no governo Costa e Silva, já pareciam ter-se definido por uma estratégia de pressão em favor do "endurecimento" político. O movimento estudantil parece ter fornecido os principais pretextos para sua função. Assim, a radicalização da direita militar mais extremada parece ter-se antecipado a acontecimentos como as greves operárias de Contagem e Osasco, o emprego de táticas "foquistas" pelo movimento estudantil e o anúncio da adesão da esquerda à "luta armada". ${ }^{28}$

Essas duas hipóteses possuem um mesmo defeito em comum: superestimam a capacidade de um ator - mesmo um ator militar num "regime militar" - mobilizar os recursos políticos segundo sua vontade e seus objetivos. Além de exibir uma visão simplificada e incorreta do panorama militar no pós1967, pois atribui a promoção da radicalização do regime exclusivamente à linha

27 Depoimento citado por: GASPARI, op. cit., p. 339. Cf. também: O AI-5 já estava pronto em julho. Veja, São Paulo, 21 dez. 1977.

28 MARTINS FILHO, Movimento estudantil, p. 138-139, grifos meus. O esquema explicativo segundo o qual o fechamento ditatorial foi uma obra da antevisão política por parte dos setores duros do regime, que utilizavam os movimentos da oposição ou criavam situações que exigissem sua intervenção, está presente também em: GORENDER, op. cit.; e ALVES, op. cit. Para o primeiro, a trama do Ato Institucional n. 5 se consumou a frio, num momento de relativa calmaria. O movimento operário-estudantil se achava reprimido e esgotado no final do ano e não podia ser a causa determinante do fechamento ditatorial. Quartim de Moraes, reportando o testemunho do Vice-Presidente Pedro Aleixo, sobre o "caso Moreira Alves" enfatiza a "existência de um complô de extrema direita visando instaurar a ditadura total. Gama e Silva, nota Aleixo, não ignorava a oposição dos parlamentares à suspensão das imunidades de Márcio Alves. Mas ele queria 'criar um conflito' que serviria de pretexto 'à instalação de um regime ditatorial', tentando, dessa maneira, 'desacreditar o Congresso'”. MORAES, Les militaires et les régimes... p. 679. 
dura, ${ }^{29}$ preserva, por comparação, a corrente castellista, na verdade aqueles que, até 1967, haviam de fato tomado as decisões mais autoritárias até então (lembre-se: AI-1, AI-2, AI-3).

Hipótese 3: a terceira hipótese destaca o papel da radicalização do movimento oposicionista (seja do movimento estudantil; seja dos ensaios de luta armada) no processo de recrudescimento do regime e do fechamento ditatorial. Parte-se do pressuposto (homólogo àquele enunciado por Carlos Castello Branco) segundo o qual "as oposições são parte do sistema político"30 para se afirmar que foi na cena política (e não no interior do aparelho do Estado) que a radicalização atuou no sentido de fazer o regime desistir das tímidas tentativas de liberalização e manipulação dos setores oposicionistas, optando, afinal, pelo autoritarismo aberto. Costa e Silva

tratará [num primeiro momento] de reativar o jogo partidário, ampliará as liberdades políticas, fará apelos à união nacional. Quando cresce a oposição (passeata dos Cem Mil, primeiros atos guerrilheiros, oposição franca do MDB ao regime, Frente Ampla etc.), novamente uma oposição interna põe em xeque o governo. Essa oposição partiria da "jovem oficialidade", dos setores nacionalistas do exército e dos ultra. Como conseqüência edita-se o Ato $5 .{ }^{31}$

Hipótese 4: a quarta hipótese disponível - também "externalista" - vê o AI-5 basicamente como o resultado de uma crise parlamentar. A recusa do Congresso Nacional, em 12 de dezembro, em autorizar o governo a processar o

29 É consenso na literatura que essa tornou-se a corrente hegemônica a partir da ascensão de Costa e Silva. Ver: CRUZ; MARTINS, op. cit., p. 31; CARDOSO, Fernando Henrique. Autoritarismo e democratização. 2. ed. Rio de Janeiro: Paz e Terra, 1975, p. 201; e CARDOSO, O modelo político brasileiro, p. 76; ver também: CASTELLO BRANCO, op. cit., p. 92-93. A rigor, a "linha dura" não era propriamente um movimento político em torno de um programa original e coerente em relação à política governamental, mas, antes, uma corrente de opinião de contornos imprecisos que reunia desde nacionalistas de direita até lideranças protofascistas.

30 CRUZ; MARTINS, op. cit., p. 14-15.

31 CARDOSO, O modelo político p. 77. ver igualmente: CRUZ; MARTINS. op. cit., e SADER, Eder. Um rumor de botas (ensaios sobre a militarização do Estado na América Latina). São Paulo: Polis, 1982. Cruz e Martins insistem também no vetor do "descontentamento popular, das classes médias, de setores do empresariado e dos demais interesses contrariados, seja pela opressão autoritária, seja pelas condições econômicas", mas sem esquecer, contudo, a substituição do partido no poder, vale dizer, a transformação no perfil da coalizão dominante e suas conseqüências para redefinição da política estatal (p. 31). 
deputado Marcio Moreira Alves (MDB-GB) foi "o" evento decisivo da crise política. $^{32}$

Penso que ao centrar o foco da crise de 1968 na ação das oposições (social ou parlamentar) essas duas hipóteses explicativas tendem a tomar o jogo político por uma relação de soma-zero, onde todo o poder tirado de um lado passa necessariamente para o outro. A essência desse jogo é a disputa entre duas intransigências: uma positiva ("as oposições"), outra negativa (os militares "radicais"). De acordo com as simpatias subjetivas do analista podese imaginar a partir daí dois cenários ideais: se as oposições tivessem exigido menos, menos intensa teria sido a resposta militar; ou: se as oposições tivessem sido mais radicais, mais fácil teria sido "derrubar o governo" e pôr fim ao regime.

Há, ainda, uma quinta explicação - oferecida pela agência de espionagem e inteligência do governo norte-americano no Rio de Janeiro - que atribui o impasse político e, portanto, o aprofundamento da crise à incapacidade e inabilidade do próprio Costa e Silva:

Estabeleceu-se um ciclo de provocações dos estudantes e de repressão da polícia que deverá persistir pelo menos até que o governo faça algum movimento para implementar necessárias reformas educacionais. Os estudantes vêm repetindo reivindicações pela reforma do sistema educacional arcaico - melhores professores, melhores instalações e currículos atualizados (...) mas não se fazem ouvir. (...) Ao mesmo tempo, pressões potencialmente perigosas estão surgindo entre os militares, que são a chave da estabilidade do governo Costa e Silva. A relutância do presidente para agir sob pressão virtualmente o impediu de fazer qualquer coisa que satisfaça tanto aos estudantes quanto aos militares. Uma inação continuada deverá servir mais para agravar do que para aliviar o problema. (...) A insatisfação militar com o desempenho inepto [sic] de Costa e Silva e de alguns de seus ministros-chave poderá aumentar à mesma proporção que os distúrbios. A incapacidade [sic] do presidente de entender as forças que estão em movimento aparece com clareza na insistente atribuição das desordens exclusivamente à ação de agitadores

32 Cf. o filme-documentário do jornalista Paulo Markun, AI-5 - O dia que não existiu. Realização do Núcleo de Documentários da TV Cultura/TV Câmara, 2001. 56 min. 
profissionais, professores, políticos de oposição. De uma maneira geral, a atividade política estudantil é vista como subversiva e o estudante descontente é visto como um problema político a ser enfrentado pela mobilização de todas as forças de segurança disponíveis... ${ }^{33}$

Na verdade, essa é muito mais uma interpretação ad hoc do que propriamente uma análise causal. Funciona mais como uma confirmação do preconceito ou da indisposição dos Estados Unidos contra o segundo presidente militar (atribuindo à sua figura e a seu cargo uma centralidade e um poder que em absoluto condizia com o complexo jogo de forças político-militares no interior do aparelho do Estado) do que como explicação efetiva para a conjuntura política. Ao personalizar, acima de tudo, a possibilidade de sua solução, simplifica a natureza da crise de 1968 e transforma a saída para o impasse político em uma questão de escolha pessoal (guiada pelo bom senso) entre duas alternativas.

Penso que seja preciso enfocar esse problema a partir de uma outra perspectiva.

\section{A ideologia como variável explicativa}

O 13 de dezembro de 1968 foi o momento crucial na definição do autoritarismo militar como um processo de longa duração. Na conjuntura que vai, grosso modo, de março/abril de 1967 a outubro de 1968, se expressaram e se resolveram, ao menos temporariamente, contradições agudas, quer no interior do aparelho de Estado (e, mais especificamente, no seio do seu ramo dominante: as Forças Armadas), quer no relacionamento entre o Estado e os setores sociais que se lançaram à oposição.

Ora, tanto uma linha de interpretação (avanço do conflito social = aprofundamento do autoritarismo) quanto outra (atuação deliberada da linha dura militar $=$ fechamento ditatorial) são, se tomadas isoladamente, pouco convincentes para decifrar o resultado final da crise política. Caso não se queira

33 Central Intelligence Agency (CIA). Os inquietos estudantes brasileiros. Relatório especial. Boletim semanal. 30 ago. 1968. 13 p. Apud VENTURA, Zuenir. 1968: o ano que não terminou. Rio de Janeiro: Nova Fronteira, 1988. p. 190-191. 
simplesmente justapor as duas razões - a internalista e a externalista -, é preciso articular os seus princípios explicativos segundo um sentido preciso. Assim, uma nova hipótese poderia vincular duas arenas - a "sociedade" (mais especificamente os conflitos sociais e políticos de classes, camadas e categorias sociais) e o "Estado" (mais especificamente as lutas internas entre os grupos políticos e correntes militares) - em função de uma variável explanatória: a ideologia.

Uma explicação possível para o problema poderia, então, ser a seguinte: a radicalização do movimento das oposições em 1968, o seu caráter de massa e o papel dirigente que os estudantes cumpriram nessa conjuntura apareciam, para as cúpulas das Forças Armadas, como perigosos elementos de desestabilização não apenas do governo Costa e Silva, mas, principalmente, da "Revolução" (isto é, do regime). O Preâmbulo do AI-5 torna mais enfática essa preocupação:

O Presidente da República Federativa do Brasil, ouvido o Conselho de Segurança Nacional, e (...) considerando que (...) se torna imperiosa a adoção de medidas que impeçam sejam frustrados os ideais superiores da Revolução, preservando a ordem, a segurança, a tranqüilidade, o desenvolvimento econômico e cultural e a harmonia política e social do País, comprometidos por processos subversivos e de guerra revolucionária; considerando que todos esses fatos perturbadores da ordem são contrários aos ideais e à consolidação do Movimento de março de 1964, obrigando os que por ele se responsabilizaram e juraram defendê-lo a adotarem as providências necessárias, que evitem sua destruição, resolve editar o seguinte Ato Institucional. ${ }^{34}$

Por que essa imagem, de uma "guerra revolucionária" em marcha, tornou-se a percepção dominante no interior das cúpulas militares? Em função da leitura (ideológica) que todas as correntes militares presentes do governo Costa e Silva (castellistas, a "linha dura", a corrente "albuquerquista" e o "grupo palaciano") faziam dessa conjuntura específica. João Roberto Marins Filho insiste, com razão, que "a presença de divisões dentro do campo militar é secundária em relação à reiterada união dessas forças na defesa da "Revolução 
de 1964" e no ataque a qualquer tentativa de rearticulação autônoma do campo "político". 35

Como a "Revolução brasileira de 31 de março de 1964" - o nome oficial do golpe político-militar - tinha o firme propósito de estabelecer uma "autêntica ordem democrática", fundada "na luta contra a corrupção", "no combate à subversão e às ideologias contrárias às tradições do nosso povo", ${ }^{36}$ toda manifestação de oposição tendia a ser enquadrada numa dessas três faltas graves. O desejo expresso pela Frente Ampla em restaurar o "poder civil", o princípio eleitoral e um regime partidário menos rígido (enfim: um regime liberaldemocrático convencional) suscitava os preconceitos enraizados entre os militares frente a "política" em geral. Mesmo sem representar a restauração do populismo e seu rosário de males (caos, desordem e instabilidade), a petição da Frente de Carlos Lacerda, Jânio Quadros, Juscelino Kubitschek e, posteriormente, João Goulart lembrava, nesta altura do processo revolucionário, a corrupção e a demagogia dos "políticos profissionais". A "subversão", por sua vez, podia ser constatada em qualquer ato de insubordinação contra a autoridade militar. A vagueza dessa categoria expressava o grau de intolerância política diante do movimento estudantil, do movimento operário, do movimento revolucionário (os ensaios de luta armada) e da discreta oposição parlamentar. Enfim, as ideologias exóticas, desnecessário dizer, compareceriam na justificação do Ato 5 como o eufemismo do "comunismo" (ou, para os mais sofisticados, do "socialismo").

$\mathrm{O}$ anticomunismo consistia, provavelmente, no elemento ideológico mais renitente da visão militar do mundo desde 1935, e funcionou, na conjuntura, como um mínimo denominador comum a todas as correntes castrenses. O coronel Gustavo Moraes Rego Reis, castellista, liberal e moderado, enfatizou que, na ausência de um "projeto" e de uma "ideologia", a "Revolução" só "pensava em deter o comunismo (...) Não tinha nada de [projeto] social nem de [projeto] econômico, era o anticomunismo". Essa ideologia funcionava como o elemento de coesão entre as facções radicais e moderadas:

Aliás, os últimos e talvez únicos propósitos e princípios que asseguravam a nossa coesão eram os da preservação da disciplina e

35 MARTINS FILHO, O palácio e a caserna, p. 115. Para uma descrição do panorama militar no governo Costa e Silva, ver p. 116-120. Há aí um “quem é quem" bastante informativo de cada facção. Uma descoberta importante do trabalho de Martins Filho é a seguinte: nesse período preciso “os 'duros' não parecem ter sido o motor da nova etapa de militarização" (p. 138). Deve-se buscar a origem dessa pressão no grupo palaciano e, mais especificamente, no Gabinete Militar da Presidência da República (p. 148).

36 Preâmbulo do Ato Institucional n. 5. In: BONAVIDES, op. cit., p. 788. 
da hierarquia nas Forças Armadas e da paz social face às ameaças iminentes da ação subversiva comunista. Este era um fato incontestável". ${ }^{37}$

Do lado costista, nacionalista e radical, para permanecer na terminologia usual, os mesmos valores, somente mais exaltados, compunham o quadro de referência comum. O depoimento do Brigadeiro João Paulo Moreira Burnier, um dos organizadores do Cisa (Centro de Informações da Aeronáutica) e integrante da "linha dura", é representativo do espírito e da disposição das forças político-militares em torno do presidente Costa e Silva na crise de 1968. ${ }^{38}$ A visão caricata do "socialismo" e a rejeição moralista do comportamento dos estudantes radicalizados à esquerda são os elementos ideológicos centrais que compõem a interpretação do momento político pela extrema-direita militar e orientam sua reação.

Sua filosofia pessoal, que retém do socialismo a idéia simplória de que se trata de um regime econômico contra o indivíduo e a liberdade de iniciativa, com base numa versão mais atualizada da fábula da cigarra e da formiga, e que enxerga na ação dos estudantes exclusivamente a manifestação patológica de uma sociedade corrompida, é menos importante pela sua ignorância do que pela sua inflexibilidade.

Sobre o socialismo: ...Tínhamos a convicção de que a ideologia marxista e socialista era impraticável para a vida, para a pessoa humana. O [ser] humano não aceita o socialismo, porque é uma doutrina econômica que dá iguais direitos a pessoas diferentes. Uma pessoa trabalha, guarda os seus recursos e consegue melhorar de vida. O outro, trabalhador também, não guarda o que ganhou, torna-se um bêbado, um sem-vergonha, e gasta todo o seu dinheiro. Não vencerá nunca. Vão ter ambos os mesmo direitos? Não. Cada um tem a sua função na sociedade, tem aquilo que merece.

37 Ver depoimento de Gustavo Moraes Rego Reis em: D’ARAUJO, Maria Celina; SOARES, Gláucio Ary Dillon; CASTRO, Celso. Visões do golpe: a memória militar sobre 1964. Rio de Janeiro: RelumeDumará, 1994. p. 60. Todas as expressões entre aspas são do coronel.

38 Burnier havia chefiado a revolta de Aragarças contra Juscelino Kubitschek. Em 1968 servia no gabinete do Ministro da Aeronáutica, Márcio de Souza Mello, ex-integralista e representante da linha dura. Ver: TRINDADE, Hélgio. O radicalismo militar em 64 e a nova tentação fascista. In: SOARES; D'ARAÚJO, op. cit.; e GASPARI, op. cit., p. 303. 
Sobre o movimento estudantil: Guardo, sim, a convicção de que esses subversivos, na sua maioria, estavam bastante enxertados das idéias, muito comuns na época, do padre Debret e de Marcuse, sobre amor livre e sobre como gozar a vida em todos os seus sentidos. Essas idéias tiveram início primeiro na França, na Sorbonne, naquele período de 68. Depois vieram para o Brasil e levaram os jovens brasileiros a se meter com drogas. Então todos eles, drogados, começando uma atividade ilegal, destruindo suas próprias juventudes, foram se transformando em verdadeiros robôs. E se imiscuíram dessas idéias de que era preciso defender a liberdade, mas uma liberdade sem limite, sem controle de direitos, sem qualquer controle de obrigações e deveres. Essas idéias começaram a perturbar a mocidade brasileira, e os subversivos marxistas se aproveitaram delas para fazer o combate à suposta ditadura militar, que de ditadura não tinha nada, pois o governo estava apenas defendendo e procurando evitar que houvesse tumulto e desordem no país. E a prova disso foi o $30{ }^{\circ}$ Congresso da UNE, em Ibiúna, estado de São Paulo, no dia 11 de outubro de 1968, que resultou na prisão de mais de 1.200 estudantes. Só vendo as fotografias para saber o que se passou lá e acreditar no que estou dizendo. Era uma fazenda alugada pela UNE onde jovens, moças e rapazes, faziam amor livre na vista de todos, tomavam drogas, um verdadeiro bacanal, uma coisa estúpida. É preciso ver a documentação da época, as fotografias, para sentir a que níveis tão baixos chegou a degradação moral desses rapazes, levados por falsos líderes, por líderes indignos. ${ }^{39}$

A severidade desse raciocínio estará na base da compreensão a respeito do grau (excessivo), da natureza (subversiva) e do sentido (contrarevolucionário) dos conflitos sociais na conjuntura de março a outubro de 1968. A avaliação contida no relatório da Central Intelligence Agency, referida acima, sobre a falta de inteligência do Marechal Costa e Silva (e, de resto, de todo o "grupo palaciano") e sua incompetência para atinar com a situação e movimentar-se adequadamente a fim de superar a crise social, revela mais preconceito do analista que percepção política. A solução final - o Ato Institucional n. 5 - resulta de um tipo específico de "análise de conjuntura", e não da ausência dela. Como Costa e Silva anunciou: a partir desse momento,

39 Cit. a partir de seu depoimento a: D’ARAUJO, Maria Celina; SOARES, Gláucio Ary Dillon; e CASTRO, Os anos de chumbo: a memória militar sobre a repressão. Rio de Janeiro: Relume-Dumará, 1994. p 201-202; 209-210, respectivamente. 
"ou a Revolução continua, ou a Revolução se desagrega". ${ }^{40}$ A acuidade da previsão é bem menos importante do que sua proposição.

O desenvolvimento dessa nova hipótese sobre a crise de 1968 e sua solução exigiria, portanto, uma análise detida da formação intelectual, das influências, dos valores políticos e das idéias sobre a (boa) organização da sociedade da corrente ideológica que assumiu, nesse contexto, a hegemonia no aparelho militar. Igualmente, exigiria um inventário de seus recursos de poder para avaliar a capacidade de ou impor a sua interpretação da conjuntura política ou a saída política para a crise política.

Como explicar as razões da derrota política das oposições e o fracasso do movimento antiautoritário?

Uma crônica de Nelson Rodrigues ("Um pesadelo com cem mil defuntos", escrita para $O$ Globo, em fevereiro de 1969) fornece, por meio de anotações impressionistas, mas bastante intuitivas, uma indicação sugestiva a propósito da configuração social do maior evento de massa de 1968:

...apanhei o número de Manchete referente à passeata dos Cem Mil. (...) E, então, comecei a repassar as fotografias dos Cem Mil. (...) Como se sabe, convém não confiar muito na memória. Todos nós somos vítimas de falsas lembranças. Sim, a memória tem suas alucinações. (...) Mas a fotografia não costuma mentir. Não sei se estavam presentes os Cem Mil. Talvez os Cem Mil fossem, digamos, a metade e, portanto, Cinqüenta Mil. De qualquer forma, eis uma massa bastante apreciável. (...) Até aquela data, só o futebol conseguiu juntar 50 mil brasileiros. (...) Cada qual levava no bolso a sua ideologia, que era a mesma em todos os bolsos. Na época, escrevi que não se encontrava, entre os Cem Mil, ou cinqüenta, ou até 25, nenhum preto. Eu estive lá espiando. Fui testemunha auditiva e ocular da marcha. Como sou uma "flor de obsessão", não me saía da cabeça a ausência do negro. Se eu descobrisse um não dois ou três, mas um, somente um -, já me daria por muito satisfeito. (...) E outra observação, que me deu o que pensar: - os Cem Mil tinham uma saúde dentária de anúncio dentifrício. Objetará alguém que muitos estariam de boca fechada. Absolutamente. Estava todo mundo de boca aberta (como no dentista) e gritando: "Participação! Participação! Participação!”. E a marcha de 100

40 Frase pronunciada pelo presidente Costa e Silva na abertura da reunião do Conselho de Segurança Nacional em 13 de dezembro de 1968. Apud GASPARI, op. cit., p. 333-334. Ainda o Preâmbulo do Ato 5: referindo-se ao Ato Institucional n. 2, que fixara o princípio segundo o qual a Revolução não "foi”, mas "é e continuará", conclui-se que é somente com as medidas do AI-5 que "o processo revolucionário em desenvolvimento não [será] detido”. Ato Institucional n. 5. In: BONAVIDES, op. cit., p. 788. 
mil sujeitos sem uma cárie, sem um desdentado (...) O fato é que, no dia seguinte, falando com o meu amigo Guilherme da Silveira Filho, fazia eu um escândalo amargo: - "Nem um preto, Silveirinha! Nem um desdentado! Nem um favelado! Nem um torcedor do Flamengo! Nem um assaltante de chofer". Por fim, arranquei das minhas entranhas este gemido final: - "E o povo? Onde está o povo?". O povo era a ausência total. (...) Não havia um preto, ou um torcedor rubro-negro, ou um desdentado, porque aquilo era uma passeata das classes dominantes. ${ }^{41}$

Descontado o tom e a tentação para a caricatura, essa impressão clara e precisa dos acontecimentos traduz uma dificuldade real do movimento contra o "regime militar": seu caráter de "massa" esconde, mas não resolve, a heterogeneidade política e ideológica no seu interior, heterogeneidade essa derivada basicamente da presença de classes, camadas e categorias sociais com idéias diferentes e com projetos políticos no limite contraditórios. A primeira e mais elementar dificuldade do movimento oposicionista reside na sua incapacidade de realizar alianças extra-classe, "para baixo", i. e., em direção à classe operária e aos setores populares urbanos - nesse sentido, a escassez de "povo" na Passeata é testemunha dessa realidade. Mas há mais dois impedimentos básicos que travam essa luta. Décio Saes identifica, apropriadamente, suas naturezas. Trata-se de um impedimento ideológico e de um impedimento político.

Do ponto de vista ideológico, as forças de oposição ao regime de 1964

estão atadas ao passado: suas formas de luta são as definidas em função de sua posição no sistema político populista. A média burguesia [industriais, comerciantes, fazendeiros] se recusa a fazer "alianças de classe"; as camadas médias tradicionais [profissionais liberais e o movimento feminino] continuam a esgrimir seu liberalismo utópico [a luta abstrata por "democracia"]; e a classe operária e as baixas camadas médias não chegam a desembaraçarse do culto populista do Estado, ${ }^{42}$

41 RODRIGUES, Nelson. O Reacionário: memórias e confissões. São Paulo: Cia. das Letras, 1995. p. 27-29.

42 SAES, op. cit., p. 213. 
exceto alguns dos seus setores mais avançados.

Além disso, as dissensões internas do movimento estudantil - em torno principalmente da sucessão na sua entidade, a UNE - e o agravamento da repressão policial-militar conduzem esse setor à paralisia política depois de outubro de 1968, como já se notou.

Do ponto de vista político, o movimento estudantil lida com um impulso essencialmente revolucionário (embora esse não fosse o único em seu interior), enquanto que o movimento feminino e de profissionais de classe média lida com um impulso utópico. Para esse último setor, o combate ao regime autoritário e à militarização do Estado não se define como um momento tático de uma grande estratégia global de "luta-revolucionária-popular-e-antiimperialista", mas, diferentemente, como a condição da restauração de um regime democrático antipopulista que pudesse dotar as "elites culturais" de maior influência sobre o processo decisório, controlado progressivamente pelos militares desde $1964 .{ }^{43}$

Achamo-nos, dessa forma, diante de um impasse intransponível nessa conjuntura: a oposição burguesa deseja a "redemocratização" do país, mas revela-se incapaz de mobilizar outros setores sociais para esse objetivo; as camadas médias tradicionais, lideradas pelo movimento estudantil, ao exprimirem sua plataforma política: a "verdadeira democracia" (i. e., as formas de representação política antipopulistas) conflitam com os projetos muito mais radicais de uma facção dos estudantes. Portanto, dos impedimentos relativos que um setor de oposição coloca a outro (aliado ao movimento repressivo crescente do Estado), calçou-se o terreno para a vitória dos grupos que, dentro e fora do aparelho do Estado, impunham a necessidade do aprofundamento do autoritarismo. O Ato 5 foi o seu começo. 


\section{Referências}

ALVES, Maria Helena Moreira. Estado e oposição no Brasil (1964-1984). Petrópolis: Vozes, 1984.

BONAVIDES, Paulo. História constitucional do Brasil. 3. ed. Rio de Janeiro: Paz e Terra, 1991.

CARDOSO, Fernando Henrique. Autoritarismo e democratização. 2. ed. Rio de Janeiro: Paz e Terra, 1975.

CARDOSO, Fernando Henrique. O modelo político brasileiro e outros ensaios. 4. ed. São Paulo; Rio de Janeiro: Difel, 1979.

CASTELLO BRANCO, Carlos. Os militares no poder. Rio de Janeiro: Nova Fronteira, 1978. v. 2: O ato 5.

CODATO, Adriano Nervo. Determinantes da crise política de 1968: conflitos militares e lutas sociais. Departamento de Ciências Sociais/Universidade Federal do Paraná, 1997, digit.

CRUZ, Sebastião Velasco; MARTINS, Carlos Estevam. De Castello a Figueiredo: uma incursão na pré-história da "abertura”. In: SORJ, Bernardo; ALMEIDA, Maria Hermínia Tavares de (Orgs.). Sociedade e política no Brasil pós-64. 2. ed. São Paulo: Brasiliense, 1984.

D’ARAÚJO, Maria Celina; CASTRO, Celso (Orgs.). Ernesto Geisel. Rio de Janeiro: Editora Fundação Getulio Vargas, 1997.

D’ARAUJO, Maria Celina; SOARES, Gláucio Ary Dillon; CASTRO, Celso. Visões do golpe: a memória militar sobre 1964. Rio de Janeiro: Relume-Dumará, 1994.

D’ARAUJO, Maria Celina; SOARES, Gláucio Ary Dillon; CASTRO, Celso. Os anos de chumbo: a memória militar sobre a repressão. Rio de Janeiro: Relume-Dumará, 1994.

DREIFUSS, René A.; DULCI, Otávio S. As forças armadas e a política. In: SORJ, Bernardo; ALMEIDA, Maria Hermínia Tavares de (Orgs.). Sociedade e política no Brasil pós-64. 2. ed. São Paulo: Brasiliense, 1984.

FERNANDES, Florestan. Apontamentos sobre a "Teoria do Autoritarismo". São Paulo: Hucitec, 1979.

GADDIS, John Lewis. Paisagens da História: como os historiadores mapeiam o passado. Rio de Janeiro: Campus, 2003.

GASPARI, Elio. A ditadura envergonhada. São Paulo: Cia. das Letras, 2002.

GOMES, Lúcia M. Gaspar. Cronologia do primeiro ano do governo Costa e Silva. Dados, n. 4, p. 199-220, 1968.

GORENDER, Jacob. Combate nas trevas. A esquerda brasileira: das ilusões perdidas à luta armada. São Paulo: Ática, 1987. 
MAGALHÃES, Irene Maria et al. Segundo e terceiro ano de governo Costa e Silva. Dados, n. 8, p. 152-233, 1971.

MARKUN, Paulo. AI-5 - O dia que não existiu. Realização do Núcleo de Documentários da TV Cultura/TV Câmara, 2001. 56 min.

MARTINS FILHO, João Roberto. Movimento estudantil e ditadura militar: 19641968. Campinas: Papirus, 1987.

MARTINS FILHO, João Roberto. O palácio e a caserna: a dinâmica militar das crises políticas na ditadura (1964-1969). São Carlos: Editora da UFSCar, 1995.

MORAES, João Quartim de. A mobilização democrática e o desencadeamento da luta armada no Brasil em 1968: notas historiográficas e observações críticas. Tempo Social, São Paulo, v. 1, n. 2, jan./jun. 1989.

MORAES, João Quartim de. Les militaires et les régimes politiques au Brésil de Deodoro à Figueiredo (1889-1979). Thèse (Doctorat d'Etat). Paris, Institut d'Etudes Politiques de Paris, datilo, 1982.

O’DONNELL, Guillermo. Reflexiones sobre las tendencias de cambio del Estado burocrático-autoritário. Revista Mexicana de Sociologia, México, v. 39, n. 1, ene./mar. 1977.

OLIVEIRA, Eliézer Rizzo. As forças armadas: política e ideologia no Brasil. (19641969). Petrópolis: Vozes, 1976.

OLIVEIRA, Eliézer Rizzo. Conflits militaires et décisions sous la présidence du Général Geisel. In: ROUQUIÉ, Alain. (dir.). Les partis militaires au Brésil. Paris: Presses de la FNSP, 1980.

POULANTZAS, Nicos. La crise des dictatures. Portugal, Grèce, Espagne. Paris: Seuil, s.d. RODRIGUES, Nelson. O Reacionário: memórias e confissões. São Paulo: Cia. das Letras, 1995.

SADER, Eder. Um rumor de botas (ensaios sobre a militarização do Estado na América Latina). São Paulo: Polis, 1982.

SAES, Décio. Classe média e sistema político no Brasil. São Paulo: T. A. Queiroz, 1984

SOARES, Gláucio Ary Dillon. O golpe de 64. In: SOARES, Gláucio Ary Dillon; D’ARAÚJO, Maria Celina (Orgs.). 21 anos de regime militar: balanços e perspectivas. Rio de Janeiro: FGV, 1994.

STEPAN, Alfred. The Military in Politics. Changing Patterns in Brazil. Princeton: Princeton University Press, 1971.

TRINDADE, Hélgio. O radicalismo militar em 64 e a nova tentação fascista. In: SOARES, Gláucio Ary Dillon; D’ARAÚJO, Maria Celina (Orgs.). 21 anos de regime militar: balanços e perspectivas. Rio de Janeiro: Ed. da FGV, 1994.

VENTURA, Zuenir. 1968: o ano que não terminou. Rio de Janeiro: Nova Fronteira, 1988. 